preservation of oral traditions, local archives, and other historical material, and the exchange of information concerning such collections; the preparation and publication of monographs and surveys, on the lines of the Ethnographic Survey produced by the International African Institute. A number of recommendations emphasized the need for physical and biological studies of African populations, including studies of physical, psychological, and mental development, and the influence of heredity, cultural environment, diet, and health. Others were concerned with the study of African languages, and proposals were made for the setting up of an Inter-African Committee for Language Problems and of a committee for organizing the recording and translation of traditional literature; the need for closer co-operation between linguists and other workers in the social sciences in Africa was stressed, and a proposal was made for the compilation of a list showing the state of linguistic documentation (i.e. descriptions, lexicons, texts) for each African language. Recommendations were also made for the systematic investigation, by linguists and anthropologists, of certain specific groups (Pygmies, Bushmen, Hottentots, Teke) as well as of the Creole languages in West Africa, and of various vehicular languages such as Pidgin. A number of recommendations dealt with the desirability of establishing close and permanent relations between workers in the social sciences and the Administrations of African territories, and securing, through CCTA, co-operation between member governments in this connexion. Recommendations were made as to studies which could usefully be undertaken on such topics as the evolution of traditional social systems, the role of educated Africans in the community, the evolution of systems of land tenure, the development of rural communities, economic development and the productivity of African labour, African law and custom and its development and application. In the fields of atchaeology and pre-history, recommendations were made regarding the preservation of sites, the investigation and recording of material by qualified persons, and the publishing of catalogues of archaeological material. A number of recommendations concerned measures to be taken to foster the study of African art in all its forms and to encourage African artists.

Particular stress was laid in many of the recommendations on the need for the exchange of information and the co-ordination of studies and researches being carried out by the various disciplines in all areas of Africa. This work of co-ordination and information is the primary purpose for which CCTA/CSA, with its numerous dependent committees, was constituted.

\title{
World Health Organization
}

THE fifth WHO Regional Committee for Africa was held from 19 to 24 September 1955 in Tananarive, Madagascar. The participants included delegates from member states and Associate Members of the African Region south of the Sahara; the Chairman was Médecin Colonel Pierre Bernard of the Direction du Service de Santé de la France d'Outre-Mer. Dr. M. J. Candau, Director-General of WHO, spoke on the current aspects of malaria control. The Regional Director for Africa (Dr. F. J. C. Cambournac) presented his annual report, which was discussed by the Committee and approved. The Committee also discussed the health problems of the pre-school-age child in Africa and the role of the nurse in the solution of these problems. Owing to the fact that African mothers are much occupied with the care of infants, and that, moreover, they very often rely on children of 2-6 years to look after the infants while the mothers are working, it may happen that the health of these children is neglected. The Committee agreed on the need for training African public health visitors, and on the need for public health centres to organize 'schools for mothers'.

The next meeting of the Regional Committee for Africa will be held from 24 to 29 September 1956 at Luanda, Angola, when the subject of discussion will be 'Practical Public Health as a means of tuberculosis control in the African region'. 